\title{
アクリル酸，メタクリル酸をグラフト重合したポリ エチレンテレフタレート布帛の水分移動特性
}

\author{
東洋紡績株式会社総合研究所 大 口 正 勝

\begin{abstract}
WATER TRANSFER PROPERTIES OF POLY(ETHYLENE TEREPHTHALATE) FABRICS GRAFTED WITH ACRYLIC ACID AND METHACRYLIC ACID
\end{abstract}

\author{
By Masakatsu Ohguchi
}

(Katata Research Center, Toyobo Co., Ltd., Katata 2-1-1, Ohtsu, Shiga, Japan)

The grafting of acrylic acid and methacrylic acid made poly(ethylene terephthalate) (PET) fibers hydrophilic, and Na salt form of the grafted PET showed eminent hygroscopicity and water absorbency, as reported previously. In this report, water transfer behavior of the grafted PET (Na salt form) was investigated in comparison with conventional hydrophilic fibers.

The water absorption and the water release of the grafted PET were almost similar to that of the surface modified hydrophilic PET. The amount of absorbed water measured under a load was higher than that of cotton, and the velocity of water release was faster than that of cotton.

It was considered that the grafting took place in the amorphous region of PET and formed the hydrophilic domains in a hydrophobic matrix. So, in the moisture absorbing or desorbing process of the grafted PET, some specific behavior was expected in comparison with a conventional hydrophilic fiber such as cotton. However, it became clear that the time dependence of moisture absorption and desorption of the grafted PET were also similar to that of cotton.

(Received April 24, 1986)

\section{1. 緒言}

衣服の着用感と瀻維美材の親水性とは密接に関係する といわれれ ${ }^{1 \sim 8)}$ ，報告も多い。衣料材料の構造要因を同じ とすれば,一般には親水性の高い䋐維はど快適な着用感 を与えるとされている。との場合の親水性を表わす特性 とは，発汗に基づく水分の移動特性であり，水分に関倸 した平衡状態での特性とと6に，平衡に至るまでの経時 的特性の把握が必要である。原田らは衣服内気候シミ。 レーション装㯰 ${ }^{9}$ により, 纎維素材の吸湿, 放湿の時間 依存性が，衣服内気候にとって重要な役割を果たすこ上 を指摘している ${ }^{10)}$ 。

*この報文を「合成縅稚へのビニルモノマーによるグラ フト重合(第6 派)」, 「Grafting of Vinyl Monomers onto Synthetic Fibers (Part 6)」とする。
ポリエチレンテレフタレート(PET) 繊維は疎水性で

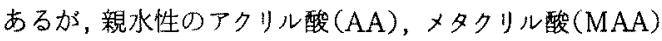
のグラフト重合によって親水化し，木綿なみの吸湿性を 得ることもできる る ${ }^{11)}$ 。グラフト重合によって踈水性合成 繊維を親水化した報告は少なくないが，いずれの場合も その親水特性としては水滴吸収時間や平衡吸湿率など， 平衡状態での特性が示されているのみで，経時的な水分 移動特性を扱ったものはない。

なお，AA，MAAをグラフト重合したPET綫維は， 蹯水性非晶領域の中に，親水性高分子が混合されたよう に不均一分布するモザイック調構造をとるととが，すで 亿報告した系物性 ${ }^{12)}$ および水中での動的粘弾性挙動 ${ }^{19)}$ から想定される。グラフト重合で PET に導入される親 水性の高分子，たとえばポリアクリル酸あるいはその $\mathrm{Na}$ 塩は，天然の漞水性高分子以上の吸湿性をむつ ${ }^{14}$ 。 
こういう親水性高分子が不均一分布したグラフトPET 䋐維の水分移動特性を，既存の親水性瀻維のそ九と比心 るととは，グラフト重合で得られる親水性 PET 繊䊒の 実用化によって有用な情報となる。既存の親水性䋐維と して天然䋐維があげられるが，紡績のし易さや実用性な どを含めて，木綿 ${ }^{16)}$ がその代表格である。

本報では，既報の方法 ${ }^{12}$ でAA，MAAをグラフト重 合したPET 㵶維の水分移動特性として, 吸水放水拈よ び吸湿放湿わ経時的変化をとりあげ，木綿または木綿を 混合したPET 緎維よ, 後加工法によって瀻維表面だけ を親水化したPET 纎維上の此較を行なったここで, 吸水放水性亡は液体状態门水の吸脱着に，吸湿放湿性亡 は気体状態の水の収脱着に対応寸る現象である防。

\section{2. 実 験}

2.1 試 料

精練，ヒートセットずみのPET仮撚加工系インター ロック(75デニール/36フィラメント. 東洋紡ポリエス テル)と，こ扎既報の力法 ${ }^{12)}$ でAA/MAA(2.5/7.5乇 ル比をダラフト重合し Na塩化したあのを試料にした。 グラフト率は，9.2\%と $14.8 \% 02$ 水準とした。

比皎試料として，上記の PETインターロックにブロ ック型ポリエステルポリオキシエチレン漞水化㨈を，固 班分として 0.7 重量\%付与して熱固着した表面親水化 PET (SR-PET)，樹脂加工などの仕上げ加工をして ない木綿の平編およびポリエステルステープル/木綿 (65/35, 重量比) 混紡系 ( $\mathrm{E} / \mathrm{C}$ 混) の平編とを選んた゚。 とれら試料の厚み，重量(目付け)，20亿における 65 \% RHट 98 \% RHでの平衡吸湿率およびJIS L 1018 に よる水滴吸収速度（ウィッキング性）を，表1に示す。 SR-PETは織維表面だけが親水化されたあので，水滴
吸収速度は速いが，吸湿性は未变性 PET と大差ない。 なお，表中の厚みは圧缩弾性試駼機により，試料に $1 \mathrm{~g}$ $/ \mathrm{cm}^{2}$ の荷重索かけて测定したものである。

\section{2 吸水性}

Larose ら ${ }^{17)}$ が報告している布帛の吸水測定装置に染 じ，図1のラローズ法吸水测定装置 ${ }^{18)}$ 作った。しの装

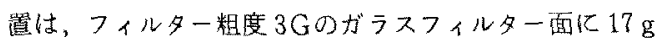
$/ \mathrm{cm}^{2}$ の荷重を受けて密着している直佳 $6 \mathrm{~cm}$ の試料布 舅が, $5 \mathrm{~cm}$ のネガティブヘッドを有する水を吸い上げる 様子を，経時的に吸水量として測定する。乙の測定法は， 発汗した肌加ら衣服材料への，液状汗の移動をモデル的 に評価するすのである。

\section{3 吸水と拡散による放水性}

重さがわかっている $8 \mathrm{~cm} \times 8 \mathrm{~cm}$ の正方形がラス板を 水平に維持し，この上にマイクロシリンジによって，1 滴が $40 \mu 1$ の水滴 13 滴を格子状に均一に分布させての せた。秤量して水の重さを求め，值ちに重さが知知の8 $\mathrm{cm} \times 8 \mathrm{~cm}$ の試料布帛を，水商ののったガラス面に密着 させてのせたあと、試料，水とガラス板の全重量を経時 的に秤量した。測定結果加ら，初めの水分に対する所定 時間に括りる残存水分の重量割合(保持率)を求め，ガラ 及板上の水が試料に吸水されて搪散し，反対面から放水 される状沅を把握した。この測定は，衣料材料に吸収さ れた液状汗が，蒸発によって放出される挙動をモデル的 亿調べるあのである。なお，測定雾囲気は 20 C，65\%

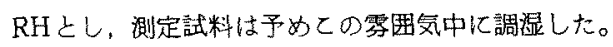

\section{4 吸湿性}

$50^{\circ} \mathrm{C}$ で減圧乾燥し絶乾した $8 \mathrm{~cm} \times 8 \mathrm{~cm}$ の試料を, $20^{\circ} \mathrm{C}, 65 \% \mathrm{RH}$ 雺囲気(恒温恒湿室)に放置したときの 吸湿量の变化を，非接触ストレインゲージを用いて，経 時的に測定した。3枚の試料について測定し, 平均値を

Table 1 Evaluated samples

\begin{tabular}{|c|c|c|c|c|c|c|c|}
\hline No. & Material & Fabric & $\begin{array}{c}\text { Thickness } \\
\text { (mm) }\end{array}$ & $\begin{array}{l}\text { Weight } \\
\left(\mathrm{g} / \mathrm{m}^{2}\right)\end{array}$ & $\begin{array}{l}\text { Moisture } \\
\frac{20^{\circ} \mathrm{C}}{65 \% \mathrm{RH}}\end{array}$ & $\begin{array}{l}\text { regain at } \\
(\%) \\
98 \% \mathrm{RH}\end{array}$ & $\begin{array}{c}\text { Wicking } \\
(\mathrm{s})\end{array}$ \\
\hline 1 & PET & inter lock & 0.96 & 210 & 0.45 & 0.72 & $180<$ \\
\hline 2 & $\begin{array}{l}\text { AA/MAA } 9.2 \% \text { grafted } \\
\operatorname{PET}(\mathrm{Na} \text { salt form })\end{array}$ & inter lock & 1.15 & 265 & 3.35 & 7.83 & $1>$ \\
\hline 3 & $\begin{array}{l}\text { AA/MAA } 14.8 \% \text { grafted } \\
\text { PET (Na salt form) }\end{array}$ & inter lock & 1.17 & 283 & 6.98 & 17.70 & $1>$ \\
\hline 4 & $\begin{array}{l}\text { SR-PET (modified PET } \\
\text { treated with hydro- } \\
\text { philic agent) }\end{array}$ & inter lock & 0.90 & 213 & 0.58 & 0.96 & $1>$ \\
\hline 5 & $\begin{array}{l}\mathrm{PET} / \text { Cotton ( } 65 / 35 \text { by } \\
\text { wt.) }\end{array}$ & plane knit & 0.60 & 116 & 2.70 & 8.64 & 1 \\
\hline 6 & Cotton & plane knit & 0.58 & 123 & 7.75 & 24.00 & 1 \\
\hline
\end{tabular}




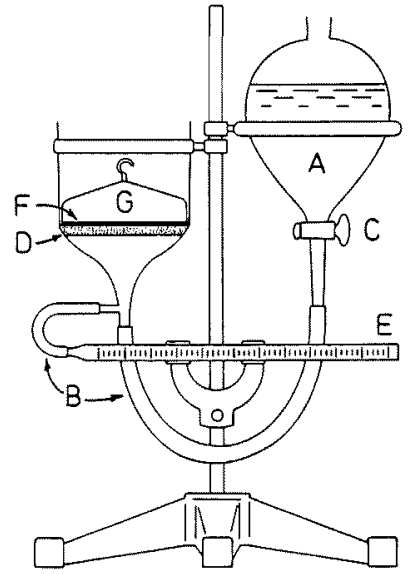

Fig. 1 Water absorbing apparatus

(Larose method) $^{18}$ )

Aiter supplying water from tank (A) to measuring part through flexible tube (B), cock (C) is closed. Excess water on the surface of glass filter (D) is absorbed and wiped out with filter paper, and water level of measuring tube (E) which is held under $5 \mathrm{~cm}$ from glass filter is adjusted at zero point.

Sample cloth $(\mathrm{F} ; \phi 6 \mathrm{~cm})$ is put on glass filter $(\phi 6.3 \mathrm{~cm})$ and brass weight $(\mathrm{G} ; 485 \mathrm{~g}$, $\phi 6 \mathrm{~cm})$ is put quickly on sample cloth. Then amount of absorbed water is measured by $\mathrm{E}$ with time.

とった。

\section{5 放湿性}

硝酸鉛の飽和塩水溶液で調整した $20^{\circ} \mathrm{C}, 98 \% \mathrm{RH} テ ゙$ シケーター中で調湿した試料を， $20^{\circ} \mathrm{C} ， 65 \%$ RHの雾同 気に放置し，吸湿性の測定之同様に，試料数 3 にる経 時的重星变化を測定した。

\section{3. 結果と考察}

\section{1 吸水性}

液状汗が存在する肌からの吸汗性を評価する方法とし て、ラローズ法を選び，吸水性测定を行なった。PET, AA/MAA 9.2\%グラフトPET (Na塩)， SR-PET, $\mathrm{E} / \mathrm{C}$ 混求よび綿についての測定結果を，図2に示す。 PETは，時間が経過してもほとんど吸水しないのに 対し，PET 以外の試料は，いずれあ1分間以内に白重 之同等以上の水老吸収し，高い吸水性を示した。PET を除く各試料の平衡吸水量は，PET 系の親水化された 6のが相対的に高く，木線，E/C混が低い值を示した。 これらの試料において，吸水性測定前に測った厚みや瀻

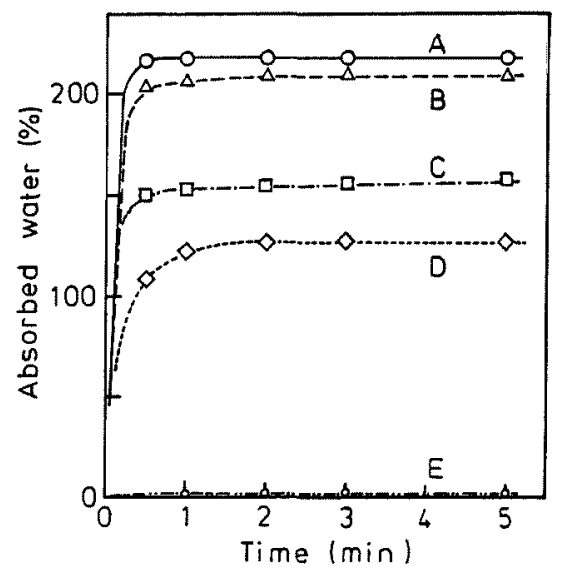

Fig. 2 Water absorbing behavior measured by Larose method

A: $9.2 \%$ grafted PET, B: SR-PET, C: PET/Cotton, D: Cotton, E: PET

維比重などから計算される気孔率 ${ }^{18,20)}$ は，82〜87\%0の 範囲にあり，平衡吸水量との相関性を示さない。

荷重がかかった状龍で吸水したときの系または試料組 織の変化上,それによって生じる吸水可能架隙の変化の 仕万に菜材間の差ができ，乙れが平衡吸水量の差として 現われたととが考えられた。るこで，17 g/cmo荷重を 加て，各試料の乾燥時の厚みに対する水にぬれた之き の厚みの比を测定したところ，PET，グラフトPET， SR-PETはそれぞれ 1.00，0.99，0.99であったが，E／ C混，木綿はをれぞれ 0.94，0.89 となり，荷重がかかっ た状態では木綿上 $\mathrm{E} / \mathrm{C}$ 混が湿潤時に空隙減少し易いこ とが確かめられた。これらの結果は，荷重下での吸水に おりる PET 系親水化素材の優位性を示すあのである。

\section{2 昅水，拡散による放水性}

ガラス板上の水滴老試料が吸収し，反対面から放出す る様子を測定した。結果を，図了に示す。

含水した布帛の乾燥過程には，恒率乾燥期と減率乾燥 期とがあり，その境目である限界水分率 (Critical moisture content : CMC) は, $100 \%$ RHでの平衡吸湿量に 相当する ${ }^{21)}$ 己されている。図 3 には，98\% RHでの吸湿 量を $\mathrm{CMC}$ とみして各試料どとに算出した CMCを， 矢印で示した。てれからかかるように，本報の放水過程 の大部分は恒率乾燥期に相当するとみなされ，試料の水 分保持率は，経過時間に対して直線的に减少した。ただ L，直線の勾配すなわち乾燥速度は，PET<木綿<SR-

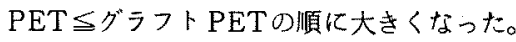

恒率乾燥期の乾燥速度は, 布帛の構造, 形態や㵶䧽の 種類に依存せず，蒸発水分と布との間には何ら相互作用 


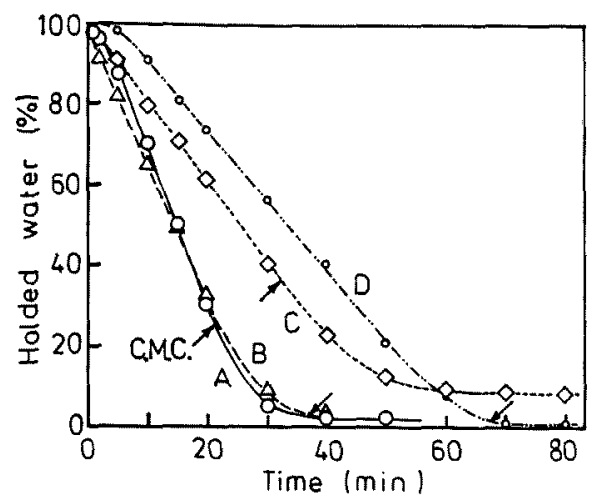

Fig. 3 Water release from fabric $(8 \mathrm{~cm} \times 8 \mathrm{~cm})$ which is put on glass plate having water droplets $(0.52 \mathrm{~g})$

A: $9.2 \%$ grafted PET, B: SR-PET, C: Cotton, D: PET

Arrow mark: critical moisture content (CMC) calculated from moisture regain at $98 \% \mathrm{RH}$ and sample weight.

がない20222)とされており，図30結泪は，てれ之異な る。本報の実験化おりる初期水分率は恒率乾燥期江相当

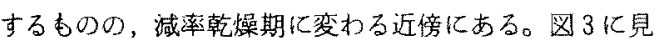
られた時間倣対する直線的水分率の娍少は，通常の恒率 乾燥機構之は異なり,ガラス接触面加ら反対面へ向け布 帛組織を通じて行なわれる吸水と拉散が定常的になり， 放水と均衡した結果である，上考えるのが妥当であるう。 なお，ガラス板上の水が試料の放水面まで移行する初期 亡，隇率乾燥期に入った後期に，直線からのずれが認め られた。

とああれ，個々の試料についてみると，PET，木綿 に比較してグラフトPET $上 \mathrm{SR}-\mathrm{PET}$ の乾懆速度が速 く，短時間に水を放出した。こ机は，布帛組織内で行な われる吸水，拡散の速さに対応しているものと考えられ る。木綿は，表 1 と図 2 亿示されたように吸水速度蛙速 いのであるが，図 3 の放水速度は遅く，疎水性のPET に近いものであった。綿の高い親水性之瀻維形龍の複 雑さのため，水が䋐維内や紡績系間隙任保持され易く， 放水側表面への移行が遅くなったもの，上解釈できる。 このと之は，長時間放水後化屯，木綿の水分保持率が他 に比へ明らか比高い值を維持していたてとからす虽づけ られる。

このように，䋘維およびその集合体である系条の複雑 さが，水の应散や放水性汇影響するようであるが，グラ ᄀトPET ${ }^{23)}$ と SR-PETの瀻維形態は，未恋性 PET 上同様に単純である。液状水の移動と蒸散を円滑に行な

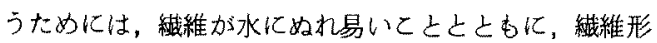
態が過度の保水をおこさない程度に笚純であることが必 要の上うに考えられる。

図了にテデーターを示さなかったが， $\mathrm{E} / \mathrm{C}$ 混の放水速 度は，木綿上 PET の中間であった。

\section{3 吸, 放湿性}

䋐維の吸, 放湿速度すなわ水蒸気濃度変化速度は,

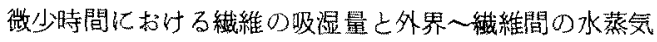
濃度差に比例するというFick の法則飞従うとされ24)， 研觉報告要多い。

吸湿過程において $a_{\mathrm{e}}$ を飽和吸湿量， $a$ を吸湿開始後 の時間 $t$ 亿扔りる吸湿量， $k$ を吸湿速度定数上すると,

$$
\log \left(a_{\mathrm{e}}-a\right)=-k t+\log a_{\mathrm{e}}
$$

の関係がある ${ }^{19,24)}$ 。また放湿過程では $d_{\mathrm{e}}$ を平衡放湿量， $d$ を放湿開始後の時間 $t$ 亿拈ける放湿量とし， $K$ 在放湿 速度定数之すると，

$$
\log \left(d_{\mathrm{e}}-d\right)=-K t+\log d_{\mathrm{e}}
$$

の関係があり ${ }^{24,26)}$ ，吸湿量あるいは放湿量の対数が，時 間 $t$ Ł 1 次の関係にある。放湿過程については，(2) 式 に上る場合 1 つの直線関係で表わすことができない2 ${ }^{26)}$ と されている。てれを単一数式モデルで表示しようとする 中島らの試み年があるが，本報では（2）式によるデータ 一整理を行なった。

AA，MAAをグラフト重合して吸湿性を付与したポリ エステル䋞維が，吸放湿の過程でどのような挙動をとる 加を明ら加をることは，吸湿性合成織維としての利用を 考える上加ら重要なとよである。そこで，20 C，65\% $\mathrm{RH}$ の条件下で木綿に近い平衡吸湿率をもつ $14.8 \%$ グラ フトPET織維編地と，てれの約 $1 / 2$ 吸湿性を示し $/ \mathrm{C}$ 混に近い平衡吸湿率をつ $9.2 \%$ グラフトPET瀻維 編地の吸，放湿速度を，木綿， $\mathrm{E} / \mathrm{C}$ 混抢よび末改算 PETと比較した。

图 4 K，絶乾試料 $20^{\circ} \mathrm{C} ， 65 \% \mathrm{RH}$ の雾囲気化置い たときの吸湿時間之吸湿率の関係を，図 5 亿，(1) 式で 示される $\log \left(a_{\mathrm{e}}-a\right)$ 上時間上の関係を示す。また図6 に, $20^{\circ} \mathrm{C}, 98 \% \mathrm{RH}$ で調湿した試料を $20^{\circ} \mathrm{C} ， 65 \% \mathrm{RH}$ の雵团気化移した之きの，経時的な水分量の変化を示し， 図7亿，(2) 式で与えられる $\log \left(d_{\mathrm{e}}-d\right)$ 上時間との関 倸を示す。上記の測定条件で得られる平衡吸湿率 $\left(a_{\mathrm{e}}\right)$ と 平衡放湿率 $\left(d_{\mathrm{e}}\right)$ は, 表 2 亿示す。

図40眨湿過程に扮いては，各試料とも初期に急激に 吸湿し，以後はしだいに緩慢になって平衡に近づく様子 が示された。図5では，2つのグラフトPETが，それ ぞれ木綿，E/C 混と類似の吸湿速度挙動をとるととが 示された。すなわち棉， $E / C$ 湿とも $\log \left(a_{\mathrm{e}}-a\right)$ と 時間 $t$ との間に 2 段階の直線関係走し，初期の約 10 


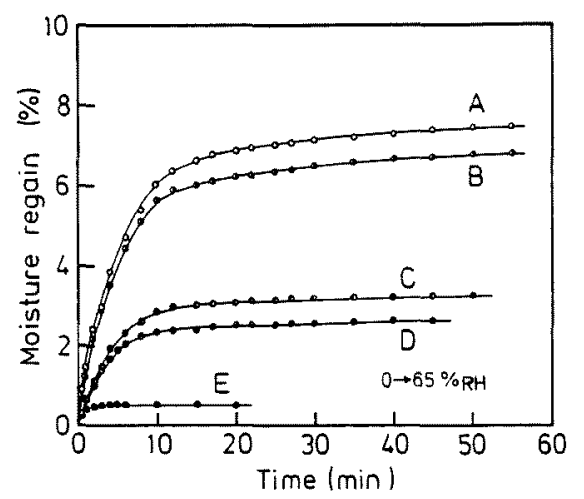

Fig. 4 Moisture absorption of dry cloth under $20^{\circ} \mathrm{C}, 65 \% \mathrm{RH}$

A: Cotton, B: $14.8 \%$ grafted PET, C: $9.2 \%$ grafted PET, D: PET/Cotton, E: PET

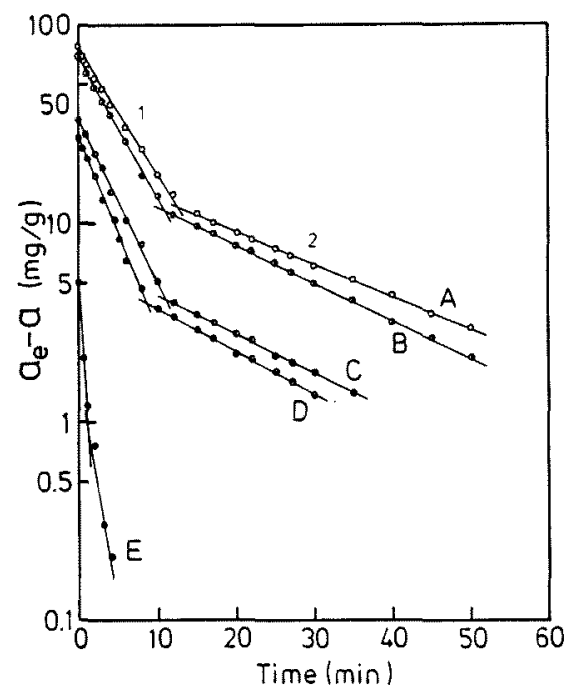

Fig. 5 Relation between $\left(a_{\mathrm{e}}-a\right)$ and time $\left(a_{e}\right)$ is equilibrated moisture regain and $(a)$ is moisture regain at time $t$.

A, B, C, D and E are the same as shown in Fig. 4.

分間における急激な吸湿のあと，穞やかな吸湿過程に入 ったが，2つのグラフトPETも，乙れらと同じ吸湿速度 の変化を示した。

これらの直楾が折れ曲がる前後で，吸湿機構によ゙のよ うな違いがあるか明らかではないが，前段階は系および 䋐維表面への水分の㠷着が中心となり，後段階では瀻維 内部への搪散と収着が中心になる，上解釉することがで

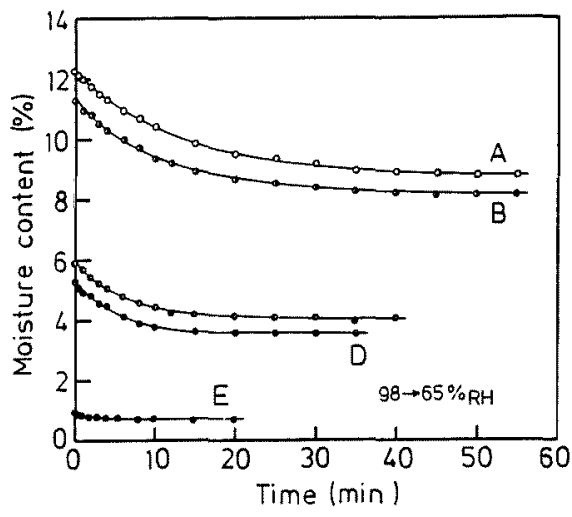

Fig. 6 Moisture desorption of cloth under $20^{\circ} \mathrm{C}$, $65 \% \mathrm{RH}$ after preconditioning under $20^{\circ} \mathrm{C}, 98 \% \mathrm{RH}$

$A, B, C, D$ and $E$ are the same as shown in Fig. 4.

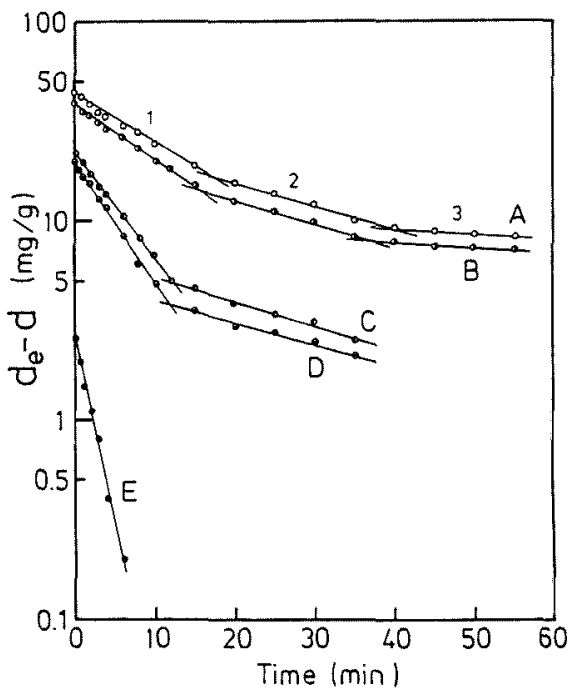

Fig. 7 Relation between $\left(d_{\mathrm{e}}-d\right)$ and time $\left(d_{\mathrm{e}}\right)$ is equilibrated desorped moisture and $(d)$ is desorped moisture at time $t$. $A, B, C, D$ and $E$ are the same as shown in Fig. 4.

きる。本報の 2 段階吸湿は丹羽らの報告 ${ }^{19)}$ 乙異なるが， 可塑剂を含む再生䋐維素皮膜の水蒸気吸着のほか，以く つかの結晶性ならびに無定形高分子上蒸気との系であ， 2 段階财着が報告されている ${ }^{26) 。 ~}$

第 1 段階，第 2 段階それぞれの吸湿速度定数を $k_{1}$ ， $k_{2}$ とし，図 5 加ら得た值を表 2 にまとめた。また $k_{1}$, $k_{2}\left\llcorner 20^{\circ} \mathrm{C}, 65 \% \mathrm{RH}\right.$ 《拈りる各試料の平衡吸湿率之の 
Table 2 Characteristic values of moisture absorption and desorption

\begin{tabular}{|c|c|c|c|c|c|c|c|c|}
\hline \multirow{2}{*}{ No. } & \multirow{2}{*}{ Material } & \multicolumn{3}{|c|}{$\begin{array}{l}\text { Absorption } \\
0 \rightarrow 65 \% \mathrm{RH}\end{array}$} & \multicolumn{4}{|c|}{$\begin{array}{c}\text { Desorption } \\
98 \rightarrow 65 \% \text { RH }\end{array}$} \\
\hline & & $\begin{array}{l}a_{\mathrm{e}} \\
(\%)\end{array}$ & $\begin{array}{c}k_{1} \\
(1 / \mathrm{min})\end{array}$ & $\begin{array}{c}k_{2} \\
(1 / \mathrm{min})\end{array}$ & $\begin{array}{l}d_{\mathrm{e}} \\
(\%)\end{array}$ & $\begin{array}{c}k_{1} \\
(1 / \mathrm{min})\end{array}$ & $\begin{array}{c}k_{2} \\
(1 / \mathrm{min})\end{array}$ & $\begin{array}{c}k_{3} \\
(1 / \mathrm{min})\end{array}$ \\
\hline 1 & PET & 0.50 & 0.620 & 0.233 & 0.70 & 0.182 & - & - \\
\hline 2 & AA/MAA $9.2 \%$ grafted PET & 3.35 & 0.082 & 0.019 & 3.75 & 0.053 & 0.012 & - \\
\hline 3 & $\mathrm{AA} / \mathrm{MAA} 14.8 \%$ grafted PET & 6.98 & 0.071 & 0.019 & 7.42 & 0.029 & 0.012 & 0.002 \\
\hline 4 & $\mathrm{PET} /$ Cotton & 2.70 & 0.097 & 0.021 & 3.30 & 0.061 & 0.011 & - \\
\hline 5 & Cotton & 7.75 & 0.065 & 0.016 & 7.98 & 0.025 & 0.012 & 0.002 \\
\hline
\end{tabular}

Moisture absorption and desorption are represented by following equations, respectively.

$$
\begin{aligned}
& \log \left(a_{\mathrm{e}}-a\right)=-k t+\log a_{\mathrm{e}} \\
& \log \left(d_{\mathrm{e}}-d\right)=-K t+\log d_{\mathrm{e}}
\end{aligned}
$$

$k$ and $K$ are rate constant of absorption and desorption. Other notations are shown in Fig. 5 and 7.

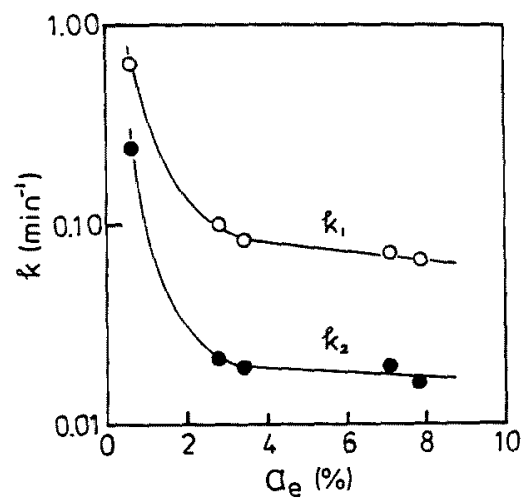

Fig. 8 Relation between equilibrated moisture regain $\left(a_{\mathrm{e}}\right)$ and rate constant of moisture absorption $\left(k_{1}, k_{2}\right)$

関係を，図8に示した。すでに多くの繊維製品について 知られているように ${ }^{19)}$ ，吸湿量の大きい瀻維の方が $k_{2}$, $k_{2}$ 上本低い值を示し,グラフトPET屯との関係から逸 脱しない己とが明らかに炕った。

图 6 に, 放湿過程であ初期に放湿量が大きく，しだい に平衡に近づく梯子が示された。吸湿量の大きい試料は ど放湿量す大さいが，平衡化達する時間は長くなる。図 $7 の \log \left(d_{\mathrm{e}}-d\right)$ 之時間 $t$ 上の関係でみると, 放湿量の 小さいPETは 1 本の直線として表わされ，(2) 式との 適合性を示した。他の放湿量の大きい試料では，木綿と グラフト率 $14.8 \%$ \% PETか段階代，E/C混とグラフ 卜率 $9.2 \%$ PETか力 2段階に折徆曲がった植線が得られ t。

同様の放湿挙動は，すでに多数報告されている。丹羽 $\zeta^{26)}$ 怯，放湿過程の第 1 段階は，試料布帛表面に保持さ れている水分および試料間腙に含まれる静止空気が急速
に拡散して放湿する段階で，試料布帛面の蒸発が主要素 として儌く段階であること，第 2 段階以降は内部拡散が 主に働いており，第 2 段階では編織系内部での搪散によ る放湿過程, 第 3 段階では繊維内部での搪散が主体の放 湿過程になるのではないか，と考察している。本報の結 果も，同じ機構で説明できる。

第7图加ら得られた，第 1 段階から第 3 段階までの放湿 速度定数を $K_{1} ， K_{2} ， K_{3}$ として表 2 亿まとめた $20^{\circ} \mathrm{C}$ ， 98\% RH 加ら $65 \% \mathrm{RH}$ 八移した之きの各試料の平衡放 湿率と $K_{1}, K_{2}$ との関係を，図 9 亿示す。第 1 段階の放 湿速度定数は，放湿量の大きい繳維はど低い值となり， 吸湿速度定数のときと同様の関係を示した。つまり，放 湿量の大きいものほど，放湿速度としては㩧くなるとと が明示された。し加し，K， 明確な相関を見出せなかった。

以上の結果から，吸湿と同様，放湿過程においてもグ

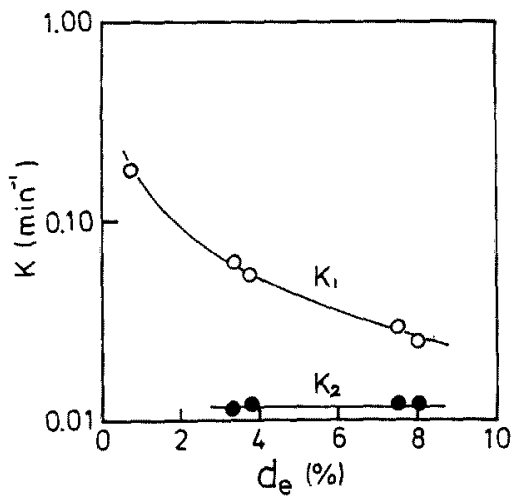

Fig. 9 Relation between equilibrated desorped moisture $\left(d_{\mathrm{e}}\right)$ and rate constant of moisture desorption $\left(K_{1}, K_{2}\right)$ 
ラフト $\mathrm{PET}$ が木綿や $\mathrm{E} / \mathrm{C}$ 混絊維と同じ挙動をとるこ よが，明らか儿なった。

すでに述べたように，AA，MAAをグラフト重合した $\mathrm{PET}$ 䄳雖は，親水性部之踈水性部とからなる構造で市 るととが想定されている。しかし，てのような縉維内の

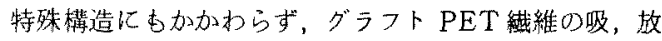
湿挙動は，木綿の上うな既存繊維と変わらないととが明 らかになった。

\section{4. 結語}

AA，MAAをダラフト重合しNa塩化して親水化した PET 縄維編地の，経時的な水尔移動特性を評価した。 その結果，グラフトPET の吸水，放水性は，繊維表面 のみ親水性化合物で被繁したSR-PET と良く似た挙 動を示し，荷重下での吸水量は木綿上り多く，吸水拡散 による放水性は木綿より速いことが示された。

グラフトPETは，親水性高分子が踈水性非晶領域に モザイック調に分布した構造をとると想定されるが，そ の吸湿および放湿の経特的変化は特䔬な香のではなく， 天然の木綿と同じパターンになることも明らかになっ た。

\section{文献}

1) J. H. Andreen, J. W. Gibson, O. C. Wetmore; Text. Res. J., 23, 11 (1953)

2) J. L. Spencer-Smith; Text. Res. J., 36, 855 (1966)

3) 平山順之; 緎学誌, 19，582，769(1963)

4）丹羽雅子，内野政子，森下文子；織消誌，8，249 (1967)

5）弓削 治; 緉消誌，15，261（1974）

6) 諸岡晊美，丹羽雅子；家学誌，30，320 (1979)
7) H. N. Yoon, A. Buckley; Text. Res. J., 54, 289 (1984)

8) R. N. DeMartino; Text. Res. J., 54, 516 (1984)

9）原田隆司, 土田和義, 内山 生; 轼機誌, $\mathbf{3 5}, \mathrm{P}-$ 203 (1982)

10）原田隆司，士由和義；緎譏誌，36，P-586(1983)

11) 大曰正勝, 井桁規矩二, 安村友秀; 繊学誌, 35, $\mathrm{T}-28$ (1979)：鸠野泰尚, 岡田紀夫, 桜田一郎； 日本原子力研究所大阪研究所に打りる放射線化学 の基礎研究，JAERI，5027，42(1971)など

12) 大口正勝, 安村友秀; 㵶学詰, 37, T-357(1981)

13）大口正勝；緎学勍，40, T-147 (1984)

14）滝沢 章；高分子学会編「高尔子上水分」，幸畫 房, p. $219(1972)$

15）山田都一；「被服材料学」贋川書店，p.13 (1970)

16) 大四正勝；繊学誌, 37, P-252（1981）

17) P. Larose; Am. Dyestuff Rept, 1942, (5), 105: J. H. Kettering; ibid., 1948, (2), 73: E. M. Buras, Jr., C. F. Goldthwait, R. M.

17) Kraemer; Text. Res. J,, 20, 239 (1950)

18）日本緎維製品消費科学会; 第 10 回消費性能試験法 講習会テキスト，p.36 (1983)

19)丹羽雅子, 野坂靖子; 緎消誌, 5，73(1964)

20）中島利誠，進藤 緑; 䋞学誌，37，T-347 (1981)

21) J. M. Preston, J. C. Chen; J. Soc. Dyers Col., 62, 361 (1946)

22) L. Fourt, A. M. Sookne, D. Fishman, M. Harris; Text. Res. J., 21, 26 (1951)

23) 大口正勝, 井析規矩二, 安村友秀; 緎学誌, 36, $T-435(1980)$

24) 諸肉晴美, 丹羽雅子; 实学誌, 30，328 (1979)

25）丹羽雅子、野坂靖子；繊消誌，5，247(1964)

26）小野木重治，浅井治海；䋐学誌，17，1185（1961） : 岸本 䀡; 高分子学会編「高分子と水分」, p.74, 幸書房 (1972) 